\title{
A BRIEF MORPHOLOGICAL DESCRIPTION OF A SMALL INTERNAL FRUIT GROWN IN HABANERO PEPPER (Capsicum chinense Jacq.) MAIN FRUIT
}

\section{BREVE DESCRIPCIÓN MORFOLÓGICA DE UN PEQUEÑO FRUTO INTERNO QUE CRECE EN EL FRUTO PRINCIPAL DEL CHILE HABANERO (Capsicum chinense Jacq.)}

\author{
Miguel A. Carballo-Bautista ${ }^{1}$, Fernando Moguel-Salazar ${ }^{1}$, Ligia Brito-Argáez ${ }^{1}$, \\ Jairo Cristóbal-Alejo ${ }^{2}$ e Ignacio Islas-Flores ${ }^{1^{*}}$
}

${ }^{1}$ Unidad de Bioquímica y Biología Molecular de Plantas, Centro de Investigación Científica de Yucatán. Calle 43 \# 130, Col. Chuburná de Hidalgo. 97200, Mérida, Yucatán, México. Tel. +52 (999) 942 83 30, Fax: +52 (999) 98139 00. ㄹstituto Tecnológico de Conkal. Antigua Carretera Mérida-Motul Km. 16.3. 97345, Conkal, Yucatán, México.

* Autor para correspondencia (islasign@cicy.mx)

\section{SUMMARY}

\begin{abstract}
Morphological characterization of habanero pepper (Capsicum chinense Jacq.) showed that chilli fruit occasionally contains a small internal fruit (SIF) developing inside the main fruit. SIF morphology showed a normal fruit with pericarp, two locules and small reminiscent ovules joined to placental-like tissues. Histological analysis showed that SIFs maintain physical connexion with the placental tissues of the main fruit through vascular tissues. A HardyWeinberg analysis suggested that the frequency of SIF formation in the Capsicum chinense population studied is not the result of natural selection. This is the first report on this morphological abnormality in Capsicum chinense and constitutes an initial attempt to explain SIF formation frequency in this chilli pepper.
\end{abstract}

Index words: Capsicum chinense, fruit development, morphological and histological fruit characterization, small internal fruit.

\section{RESUMEN}

La caracterización morfológica del fruto de chile habanero (Capsicum chinense Jacq.) mostró que el fruto principal ocasionalmente contiene un pequeño fruto interno, aquí denominado "small internal fruit" (SIF). La morfología SIF fue normal, pues tiene pericarpio, dos lóculos y reminiscencias de óvulos unidos a una región parecida a la placenta. Los análisis histológicos mostraron que los SIFs mantienen una conexión vascular con el tejido placentario del fruto principal. Un análisis de Hardy-Weinberg en una población de chile habanero indicó que la frecuencia de la formación de SIF no es resultado de la selección natural. Este es el primer reporte de la caracterización de este fruto en Capsicum chinense y constituye un primer esfuerzo para explicar la frecuencia de formación de SIFs, en esta especie.

Palabras clave: Capsicum chinense, desarrollo del fruto, caracterización morfológica e histológica de fruto, pequeño fruto interno.

\section{INTRODUCTION}

Peppers are grown worldwide and are highly appreciated for their spicy flavor and nutritional value (Heuvelink and Körner, 2001). Research on chilli plants has focused primarily on increasing plant yield and improving fruit quality and pungency (Blum et al., 2003; Stewart et al., 2005). Chilli fruit set and load vary depending on environment, plant genetics and physiological conditions (Aloni et al., 1999). Low fruit set and load in the Tropics prevents high yields, being temperature one of the main environmental factors responsible (Aloni et al., 1999). Chilli fruit set, shape and size are genetically determined, which in turn are mainly determined by polygenic inheritance (Chaim et al., 2001).

One of the hottest known chillies is the habanero pepper (Capsicum chinense Jacq.). It is mainly cultivated in the Yucatán Península, México, by small farmers who sell the fruit in the local market or to local processors (Cázares-Sánchez et al., 2005). Demand for habanero pepper fruit from Yucatán has recently increased in the international market (González-Estrada, 2006). It is exported fresh to Canada, Europe, Japan, Korea and the USA, where it is used to enhance spicyness of food. It is also processed for its derivates which are used in personal self-defence products (e.g., pepper spray) and for treating pain from neuropathies (Islas-Flores et al., 2005).

Capsicum chinense fruit is still poorly characterized because other chillies such as $C$. annuum have higher demand. The growing international market for habanero 
pepper, however, has increased the demand for hotter and larger fruits. As part of the research aimed at characterizing $C$. chinense fruit, the morphological characteristics of fruits from plantations in Yucatán, México was analyzed. Small internal fruits (SIF) were identified inside some mature and immature fruits. These SIFs appeared more frequently than initially expected, suggesting that this phenomenon is not particularly rare in habanero pepper. Quantitative data on the distribution of SIF occurrence was gathered through morphological characterization of habanero fruits and subsequent genetic analysis of SIF frequency. The morphological characterization of the collected small internal fruit is reported here and constitutes the first detailed description and analysis of a malformation in $C$. chinense.

\section{MATERIALS AND METHODS}

\section{Plant material}

Capsicum chinense Jacq. (cv 'Orange') fruits were collected at Puerto Chicxulub, in the state of Yucatán, México (21 ${ }^{\circ} 08^{\prime} \mathrm{LN} ; 89^{\circ} 31^{\prime} \mathrm{LW} ; 10$ masl). The sampled orchards received no agrochemical treatments nor were they protected from the weather. Drip irrigation occurred every other day at soil level. Plants $(\mathrm{n}=2200)$ were selected for analysis and their pepper fruits were harvested 3 or 4 months after planting. The fruits were checked for small internal fruits (SIF) by removal of a disc in the pericarp or by removing the entire pericarp, with a sterile knife.

\section{Fixation of small internal fruit tissue}

Using a sterile knife the pericarp was removed from fruits containing SIF. The SIF and a small piece of placental tissue were immersed in $100 \mathrm{mM}$ $\mathrm{Na}_{2} \mathrm{HPO}_{4} / \mathrm{NaH}_{2} \mathrm{PO}_{4}(\mathrm{pH} 7.0$ ), containing $142 \mathrm{mM} \mathrm{NaCl}$, $4 \%$ paraformaldehyde and $2.5 \%$ glutaraldehyde (PBSF, buffer). The solution was discarded after $96 \mathrm{~h}$. Then SIFs were washed for $1 \mathrm{~h}$ in $100 \mathrm{mM} \mathrm{Na} 2 \mathrm{HPO}_{4} / \mathrm{NaH}_{2} \mathrm{PO}_{4}(\mathrm{pH}$ 7.0), and $142 \mathrm{mM} \mathrm{NaCl}$ (PBS buffer) added. They were then dehydrated in a series of ethanol concentrations (30 to $100 \%, \mathrm{v} / \mathrm{v}$ ), with four changes of $2 \mathrm{~h}$ each, using absolute ethanol in the final step. Dehydrated SIFs were pre-included in JB-4 ${ }^{\circledR}$ resin (Polysciences) for $96 \mathrm{~h}$ under negative pressure $(150 \mathrm{~mm} \mathrm{Hg})$ using a vacuum pump (Felisa $\AA$; Michigan, USA). Embedding of SIFs was done as described above, with the addition of JB-4 embedding solution (1 mL of embedding reagent $/ 25 \mathrm{~mL}$ of resin), according to manufacturer instructions (JB-4® Embedding kit; Polysciences).
The resin-embedded SIFs were cut into $5 \mu \mathrm{m}$ slices with a microtome HM 340-E® (Microm; Waldorf, Germany), fixed on clean microscope slides (Sigma), stained with toluidine blue and washed with water until a clear contrast was attained. Permount resin (Fisher) was added to the dried and stained preparations, clean coverslides placed over them and observed in a light microscope Revelation III ${ }^{\circledR}$ (LW Scientific; Georgia, USA). Microhistological analysis was done by extracting rounded, $1 \mathrm{~cm}$-diameter sections from the apex or basal area of the SIFs, and then observing the open SIFs under 6x magnification with a dissection microscope DFC320 ${ }^{\circledR}$ (Leica; Heerbrugg, Switzerland); images were taken.

\section{Hardy-Weinberg analysis}

This analysis was done to determine if SIF frequency can be explained by gene flow and natural selection, or if is the result of artificial selection done by growers (Edwards, 2008).

\section{RESULTS}

Preliminary analyses showed that some habanero pepper fruits contain SIFs. Analysis of SIF frequency and occurrence was done by screening 2102 Capsicum chinense cv. 'Orange' plants grown under field conditions. Nine hundred and sixty-eight plants had mature orange fruits (Figures 1A and B) of which 55 were positive for SIF in mature fruit. SIF frequency was, at least, of three positive fruits per plant.

SIFs were found to develop inside the main fruit and joined to the placental tissue and were usually surrounded by the seeds (Figures 1C and D). Due to the fact that SIFs commonly developed at the tip of the placental tissue, most fruits did not usually exhibit placental tissues fused to the pericarp, and the main fruit locules were not clearly delimited. Most identified SIFs were green colored and some were orange (Figures 1C and D). SIFs were detected most frequently as a single fruit, although in a few cases two SIFs can be observed inside the same main fruit.

Microhistological analysis showed SIF size varies between 1 and $2 \mathrm{~cm}$ long and 1 and $1.5 \mathrm{~cm}$ wide, with apparently normal morphology (i.e., two locules observed in dissected SIFs). Pericarp in the analyzed SIFs was well-defined and clearly delimited; some small reminiscent ovules joined to the placental tissue were also detected in the locules (Figure 2). SIFs were found attached to the placental tissues by a tight cell connection (Figures 3A and B). Conductive vascular elements passed through the middle of the placenta (Figure 3C), and a 
small number of these specialized tissues were orientated toward the SIF or were present in the SIF-pericarp (Figure 3D). The placental tissue also contained air spaces between cells (Figure 3C). Fruits containing SIFs were found to be highly pungent and frequently contained free, liquid oleoresin in the malformed locules (data not shown).

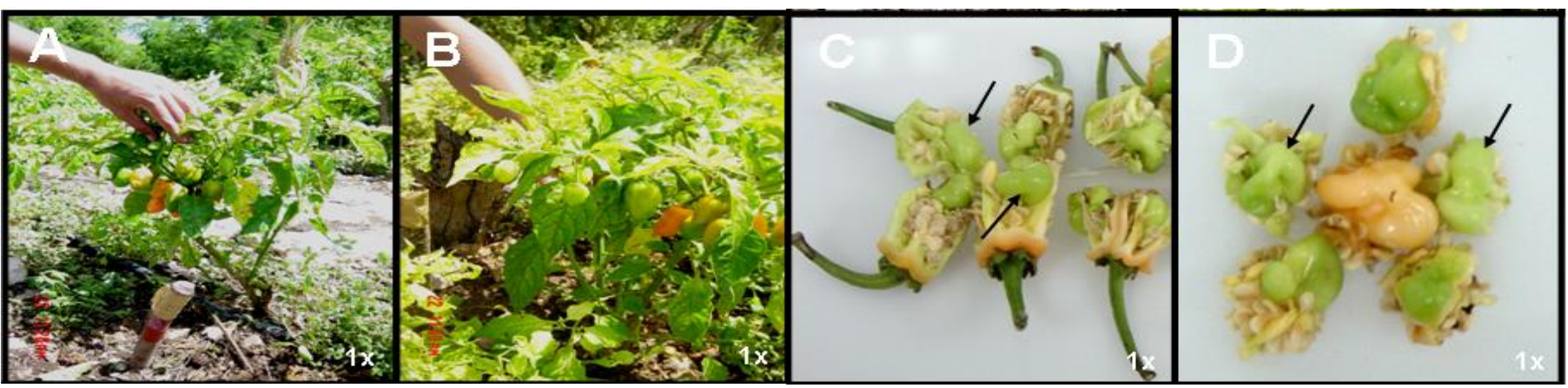

Figure 1. Capsicum chinense plants and fruits. Fruit producing plants (A, B) and de-carpelated main fruits (C, D). Arrows shows small internal fruits (SIFs) surrounded by pepper seeds.

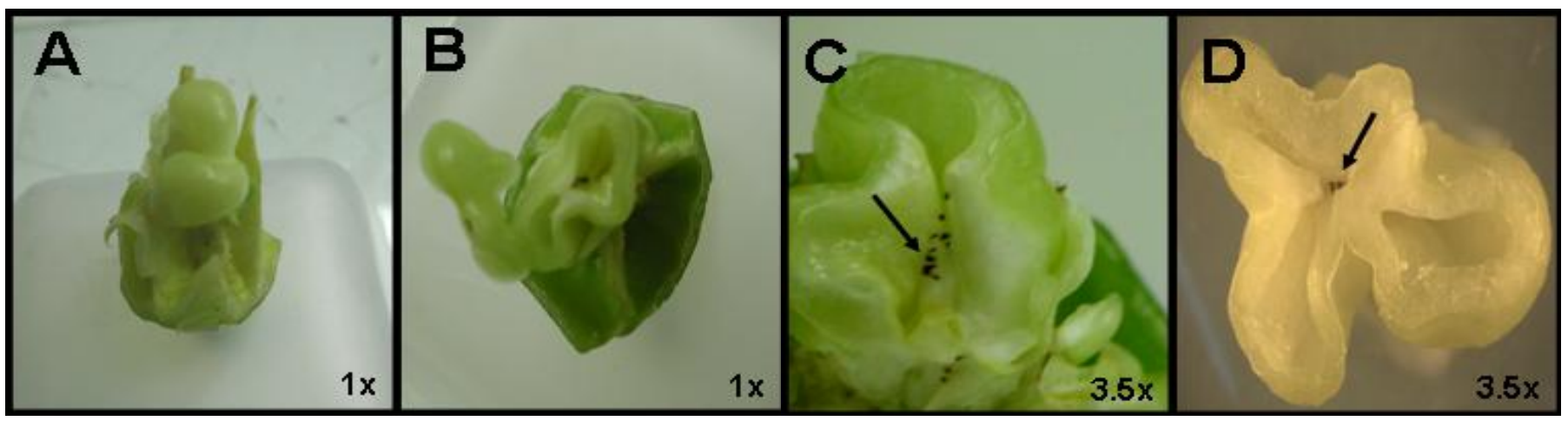

Figure 2. Morphological characteristics of small internal fruit (SIF) in Capsicum chinense. View of complete SIF morphology (A) and de-capped SIF (B). Arrows indicates reminiscent ovules in the SIF loculi $(C, D)$.

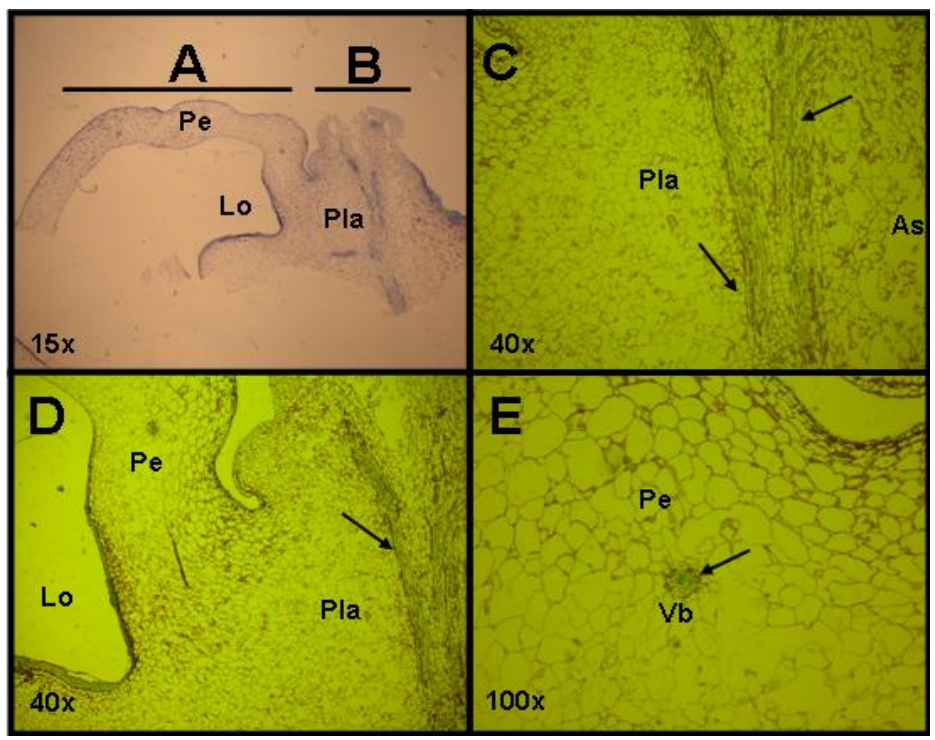

Figure 3. Microhistological analysis of small internal fruit (SIF) from Capsicum chinense showing section of a locule from SIF (A), and its connection to placental tissue of main fruit $(B)$. Magnification of placental tissue showing longitudinal sections of vascular elements (C) and cell area from where SIF-pericarp originated (D). Magnification of SIF-pericarp showing a vascular bundle (E). Arrows shows vascular elements. Pericarp (Pe), locule (Lo), placental tissue (Pla), vascular bundle (Vb), air space (As). 
Table 1. Theoretical values predicted by the Hardy-Weinberg theorem and experimental values registered for SIF formation in habanero pepper ( $C$. chinense) cv. 'Orange'.

\begin{tabular}{lcccc}
\hline Types of plants & \multicolumn{2}{c}{ Tested plants } & & \multicolumn{2}{c}{$\begin{array}{c}\text { Experimental } \\
\text { values }\end{array}$} \\
\cline { 2 - 3 } & Number & $\%$ & (AA) 560 plants & values \\
\hline Plants producing fruits & 968 & 100 & (Aa) 353 plants & (AA) 240 plants \\
& & & (aa) 55 & (Aa) 480 plants \\
(aa) 240 plants & \\
Plants showing internal fruits & 55 & 5.73 & & \\
\hline
\end{tabular}

The possibility that the presence of SIFs could be an artificially-inherited character in the analyzed Capsicum chinense plants was evaluated with a Hardy-Weinberg analysis. This was done as an initial approach to determine if SIF presence in this species could be the product of natural or artificial selection (Table 1). The theoretical values for the $p^{2}+2 p q+q^{2}$ predicted that 240 plants would be dominant (AA) and 480 plants would be associated with the heterozygous character (Aa), both of them related to development of normal fruits. The theorem also associated 240 plants with expression of the recessive character (aa), related to the presence of SIF. The experimental data showed 560 plants associated with (AA), 353 with (Aa) and 55 with (aa). These values do not nearly approximate the predicted values, suggesting that some artificial selection has taken place in the sampled pepper population.

\section{DISCUSSION}

The increasing value of habanero pepper fruit in the international market calls for selection of plants able to produce a higher number of export-quality fruits to satisfy the market demands for fresh fruit of large size, good flavor and high pungency.

During initial phenotypic characterization of habanero fruits from producers in Yucatán, which are the main suppliers in the world, internal proliferation (development of one small fruit inside the main fruit, called SIF here) was observed. Occurrence of SIF was apparently higher than expected in habanero pepper because it was assumed as a rare event. Only one previous study describes this phenomenon in chillies: Bausor (1935) hypothesized that internal proliferation in Capsicum annuum was associated with teratological events in the plant pistil. No previous reports exist to date of this phenomenon in $C$. chinense.

In the present study, the results of Hardy-Weinberg theorem suggested that SIF frequency in $C$. chinense fruit was not caused by natural selection and thus it may be the result of artificial selection. Whether or not SIF development is a character linked to fruit production remains unclear, but plants in the region have been constantly under selection for fruit production. However, if these characters are linked, then according to the present data the SIF allele shows a low frequency in the studied population.

It is unlikely that SIFs developed in response to biotic or abiotic stress, since only a few plants in the sampled area had visual symptoms of virus attack or other diseases (e.g., weevil larvae and bacterial spots).

Some of the SIF-containing fruits were rounded, but most had a normal phenotype (i.e., large, shiny pods), meaning that SIF-containing fruit are not incompatible with exportation. Preliminary organoleptic results suggested that fruits containing SIFs were more pungent than regular fruits (i.e., SIF-free). If measure of capsaicin by HPLC confirms that SIF-containing fruits are more pungent than SIF-free ones, development of markers to select SIF-containing fruits will be important to improve C. chinense agronomic traits.

In conclusion, SIFs are not deleterious for $C$. chinense international marketing. SIF-containing fruits could be selected if these fruits really are richer in capsaicin, and as such they might be added as traits. The physiological meaning of SIF growth remains unclear, but this initial morphological description of such event in Capsicum chinense fruit could contribute to a better understanding of habanero pepper fruit and for developing its agronomic potential.

\section{ACKNOWLEDGEMENTS}

To the anonymous reviewers, who kindly did valuable suggestions and improved the English text. Research was funded by Fundación Produce Yucatán, A.C., Grant No. 0203. M. A. Carballo-Bautista and F. Moguel-Salazar were supported by fellowships from CONACYT (No. 183388 and 138841, respectively).

\section{BIBLIOGRAPHY}

Aloni B, E Pressman, L Karni (1999) The effect of fruit load, defoliation and night temperature on the morphology of pepper flowers and on fruit shape. Ann. Bot. 83:529-534.

Bausor S C (1935) A monstrous fruit of Capsicum. Am. J. Bot. 22:826828. 
Blum E, M Mazourek, M A O’Connell, J Curry, T Thorup, K Liu, M Jahn, I Paran (2003) Molecular mapping of capsaicinoid biosynthesis genes and quantitative trait loci analysis for capsaicinoid content in Capsicum. Theor. Appl. Gen. 108:7986.

Cázares-Sánchez E, P Ramírez-Vallejo, F Castillo-González, R M Soto-Hernández, M T Rodríguez-González, J L ChávezServia (2005) Capsaicinoids and preference of use in different morphotypes of chilli peppers (Capsicum annuum L.) of eastcentral Yucatán. Agrociencia 39:627-638.

Chaim A B, I Paran, R Grube, M Jahn, R van Wijk, J Peleman (2001) QTL mapping of fruit related traits in pepper (Capsicum апnиит). Theor. Appl. Gen. 102:1016-1028.

Edwards A W F (2008) G.H. Hardy (1908) and Hardy-Weinberg Equilibrium. Anecdotal, historical and critical commentaries on genetics. Genetics 179:1143-1150.
González-Estrada T (2006) Habanero growing systems. Fiery Foods 42:21-23.

Heuvelink E, O Körner (2001) Parthenocarpic fruit growth reduces yield fluctuation and blossom-end rot in sweet pepper. Ann. Bot. 88:69-74.

Islas-Flores I, T González-Estrada, M A Villanueva (2005) The capsaicin: just as hot as hell?. Recent Res. Develop. Biochem. 6:121-132.

Stewart C Jr, K Byoung-Cheor, K Liu, M Mazourek, S L Moore, E Y Yoo, K Byung-Dong, I Paran, M M Jahn (2005) The Pun1 gene for pungency in pepper encodes a putative acyltransferase. Plant J. 42:675-688. 